\title{
新製品への代替を考慮した家電製品の廃棄台数予測
}

\author{
山末英嗣 1 中島謙 -2 奥村 英 $之^{1} \quad$ 石 原 慶 ${ }^{1}$ \\ 1京都大学大学院エネルギー科学研究科 \\ 2 東北大学大学院環境科学研究科
}

J. Japan Inst. Metals, Vol. 70, No. 8 (2006), pp. 611-614

(C) 2006 The Japan Institute of Metals

\section{Estimation of the Number of Discarded Home Electric Appliances Considering New Alternative Products}

Eiji Yamasue $^{1}$, Kenichi Nakajima ${ }^{2}$, Hideyuki Okumura ${ }^{1}$ and Keiichi N. Ishihara ${ }^{1}$

${ }^{1}$ Graduate School of Energy Science, Kyoto University, Kyoto 606-8501

${ }^{2}$ Graduate School of Environmental Studies, Tohoku University, Sendai 980-8579

The number of discarded home electric appliances CRT TV (CRT), liquid-crystal display TV (LCD), plasma display panel TV (PDP), refrigerator, air conditioner, washing machine, microwave oven, cleaner, video cassette recorder (VCR) and (DVD) has been estimated using a population balance model. For the estimations of CRT and VCR, the effects of alternative products (LCD and PDP, and DVD, respectively) were considered. The increasing rates of the estimated number of the discarded refrigerator, the washing machine and the cleaner from 2000 to 2020 were within $5 \%$, while those of air conditioner and microwave oven were more than 30\%. The estimated number of shipped CRT and VCR were in good agreement with those of statistic values, indicating the reasonability of the estimated number of discarded LCD, PDP and DVD. As an application of the estimated data, the amount of indium included in the discarded display panel of LCD and PDP was calculated.

(Received April 12, 2006; Accepted May 29, 2006)

Keywords: discarded electric home appliance, population balance model, recycle, social dissipation

\section{1. 緒言}

家電リサイクル法の施行 3 年後の 2003 年度において, 全 国 380 力所の指定取引場所で引き取られた廃家電 4 品目 (テ レビ, 冷蔵庫, エアコン, 洗濯機) は約 1046 万台であっ た.これらは家電リサイクルプラントに搬入後 $99.8 \%$ ザリ サイクル処理され, 鉄, 銅, アルミニウム, ガラスなどが有 価物として回収され, 再商品化率は法定の基準值を大きく上 回るテレビ $78 \%$, 冷蔵庫 $63 \%$, エアコン $81 \%$, 洗濯機 65\%であった1).

しかし，家電製品には上記のベースメタルだけでなく多種 にわたる稀少元素 (レアメタル)が含まれており, 現在のリサ イクルプロセスではこれらのレアメタルは再生金属中に希薄 に分散され，有効にリサイクルされていない場合がほとんど である。この原因の一つとして, 家電製品は消費財と異なり 平均製品寿命が 10 年程度と長く, また特に近年は家電製品 の多様化が進んだことにより廃棄台数の予測が困難となり,

リサイクル計画や適正処分計画が適正に立てられにくくなっ ていることが挙げられる. 一例として，2000 年以降に普及 し始めた液晶テレビ(LCD)やプラズマディスプレイテレビ (PDP)は, 2011 年 7 月のアナログ放送の終了とあいまっ て, 急速な出荷台数の伸びを示している一方, ブラウン管テ レビ $(\mathrm{CRT})$ は代替効果により出荷台数が激減している.
た, DVD とビデオカセットレコーダ(VCR)の関係も同様で ある2).

廃家電製品の発生台数は, 家電製品協会3), 経済産業 省 ${ }^{4}$, 日本電機工業界 ${ }^{5}$ が予測しているが，それぞれ 1998 年, 2002 年, 2003 年までしか行っていない。田崎ら ${ }^{6)} 2020$ 年まで予測を行っているが，LCD やDVDによる代替を考 慮していない。 また, 産業構造審議会環境部会7)では, LCD とPDPについて 2007 年まで廃棄台数予測を行っている が，基となるデータとして 2001 年度の出荷台数の実績デー タしか使用していない.

以上より, 本研究では, 従来行われてきた CRT, 冷蔵 庫, エアコン, 洗濯機, 掃除機, 電子レンジ, VCR の 7 品 目の廃棄台数予測に加え, LCD, PDP, DVDの 3 品目を追 加した計 10 品目の廃育台数予測を行うことを目的とする. なお，本論文では，(1)新たなる対象品目の追加，および(2)技 術変化 (LCD, PDP, DVDへの代替)を反映させることで再推 計されたデータの応用に焦点を当てており, 後者では得られ たデータを用いて家電製品に含まれるインジウムをレアメタ ルの例としてあげ，その市中拡散量の推計例を提示する.

\section{2. 解 析 方 法}

2.1 ポピュレーションバランスモデル

本研究では田崎ら ${ }^{6)}$ の提案したポピュレーションバランス 
モデルを応用し, 出荷台数, 保有台数, 使用年数分布から将 来の廃家電製品の発生台数予測を行った. すなわち $t$ 年度の 出荷台数 $P_{t}$ から $t$ 年度の廃棄台数 $W_{t}$ を差し引いたものは $t$ 年度中の保有台数の増加分と一致するため, 次のような関係 が成立する。

$$
P_{t}-W_{t}=N_{t}-N_{t-1}
$$

ただし， $N_{t}$ および $N_{t-1}$ はそれぞれ $t$ 年度と $(t-1)$ 年度の国 内保有台数である.

$t$ 年度に打ける国内保有台数 $N_{t}$ は $t$ 年度に打的世帯あた りの保有台数 $n_{t}$ と世帯数 $H_{t}$ の積として式 (2)のように表す ことができる.

$$
N_{t}=n_{t} \times H_{t}
$$

さらに $n_{t}$ はロジスティック関数を用いて式 $(3)$ のように表 すことができる。

$$
n_{t}=\frac{n_{\max }}{1+A \exp \left\{-B\left(t-t_{0}\right)\right\}}
$$

ここで， $n_{\max }$ は世帯あたりの最大保有台数， $t_{0}$ は基準年度， $A, B$ は定数である. 本研究では $t_{0}, A, B$ をパラメータと し, 過去の世帯あたりの保有台数データ2,8) から回帰分析に より決定した。 また，世帯数データは国勢調査 ${ }^{9)}$ の值を使 い, 将来の世帯数については国立社会保障 · 人口問題研究所 の推計值 ${ }^{10)}$ を用いた.

一方, 廃棄台数 $W_{t}$ は, 様々な部品の寿命関数として用い られるワイブル分布関数 ${ }^{11)}$ を用いて推計した。すなわちあ る製品が生産されて $i$ 年後に廃棄される確率を $f_{i}$ とすると, $t$ 年度の廃棄台数 $W_{t}$ は

$$
W_{t}=\sum_{i=1}\left(P_{(t-i)} \times f_{i}\right)
$$

と表すことができる. 本研究では, 出荷台数データは家電産 業ハンドブックの值 2 を用い，寿命分布は家電製品消費者使 用実態調査結果 ${ }^{12)}$ をワイブル累積分布関数で回㷌分析し, その結果からワイブル分布関数を決定した。

したがって, 式 (2) と式 (4)を式 (1)に代入することに より $t$ 年度の出荷台数を決定することが可能となる. $t$ 年度 の出荷台数が分かると, その值を基に $(t+1)$ 年度の廃棄台数 を決定することができ, さらに $(t+1)$ 年度と $t$ 年度の国内保 有台数の值から, $(t+1)$ 年度の出荷台数が決定できる. 本研 究ではこの計算を繰り返し, 出荷台数データが存在する年度 については計算結果と統計值の整合性を検討し, 大きな誤差 が発生した場合は文献值や関数近似の吟味を行った. 特に国 内保有台数に関しては, 式 ( 2 ) で用いる世帯数が非常に大 きいことから世帯あたりの保有台数データの僅かな変化が大 きな変化として現れる. そのため, 特に世帯あたりの保有台 数データ，およびそのロジスティック関数による推測值につ いては注意深く検討した. また, データ 3 点の移動平均を 用いることでデータの平滑化も行った．推算值と統計值に大 きな差が見られなくなった場合，そのデータを基に 2025 年 までの出荷台数, 廃棄台数を算出した.

\subsection{CRT, LCD, PDP, VCR, DVD の廃棄台数の予測方法}

冷蔵庫, エアコン, 洗濯機, 掃除機, 電子レンジについて は上記の手法で廃棄台数を推定できるが，CRT や VCR は
近年それぞれ LCD と PDP, DVDへの代替を考慮する必要 がある、そこで本研究では, 以下のような仮定を用いて推測 を行った。

仮定 1 LCD, PDP の寿命関数は CRT と同じとした。 (VCR と DVD も同様)

仮定 2 LCD と PDP の世帯あたりの保有台数についてロジ スティック関数で近似を行う際, LCD と PDP の最大保

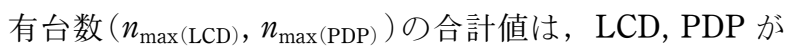
存在しないとして推計した CRTの最大保有台数 (=2.52)に一致するとした。(VCR と DVD も同様)た たし $n_{\max (\mathrm{LCD})}$ と $n_{\max (\mathrm{PDP})}$ の比は 2005 年度の保有台数 比と同じになるとした。すなわち， $n_{\max (\mathrm{LCD})}=2.2$, $n_{\max (\mathrm{PDP})}=0.32$ とした.

仮定 3 ある年度に㧍ける CRT と LCD と PDP の出荷台数 の合計は，LCD と PDP が現れなかったとしたときの CRTの出荷台数と同じになるとした．すなわち，まず LCD と PDP を考慮しない場合の CRT の出荷台数を導 出し, その後, 仮定 1 と 2 から推算した LCD と PDP の出荷台数の合計を差し引くことで CRT 出荷台数とし た.この值が負になった年度以降の CRT 出荷台数は 0 とした. (VCR とDVDも同様)

なお，現在 DVD には DVD プレーヤ，DVDレコーダ， HDD/DVD レコーダなどが存在するが，全て同一のものと して取り扱った。

\section{3. 結果および考察}

\section{1 冷蔵庫, エアコン, 洗濯機, 掃除機, 電子レンジの推 計結果}

Fig. 1 に上記の手法によって求めた結果の代表例として, 電子レンジの出荷台数拈よび廃棄台数の予測結果を示す. 電 子レンジの出荷台数の統計值と推算值は比較的良い一致を示 していることが分かる. 他の 4 品目についても同程度のよ い一致が見られた. Fig. 2 に冷蔵庫, エアコン, 洗濯機, 掃 除機, 電子レンジの廃棄台数予測結果をまとめたものを示 す. 図中には, 田崎ら ${ }^{6)}$ にる 2000 年度と 2020 年度の推定 值も示している. 冷蔵庫, 洗濯機, 掃除機については田崎ら の推定值と本研究の推定值は良い一致を示した. 一方, エア コンは 2000 年度の推計值が, 電子レンジについては 2000 年度と 2020 年度の推計值が，最大 $30 \sim 40 \%$ 程度の差が見 られた。これは, 田崎らは1998 年度までの統計值を基に推 定を行っているが, 本研究では 2005 年度までの統計值を基 にしていることが原因と考えられる. すなわち, 冷蔵庫, 洗 濯機, 掃除機の保有台数は 1998 年度においてほぼ飽和状態 にあり2)，それまでのデータを用いて推計を行ったとしても 誤差は発生しにくいが，エアコンと電子レンジの保有台数は 同時期においても増加傾向にあり，推計に誤差が生じたもの と考えられる.

2000 年度を基準として 2025 年までの廃棄台数の変化を 見ると, エアコンが約 136\%, 電子レンジが約 129\%の増加 率となり, 今後, エアコンと電子レンジのリサイクルや適正 処分をより重点的に計画する必要があると考えられる。 


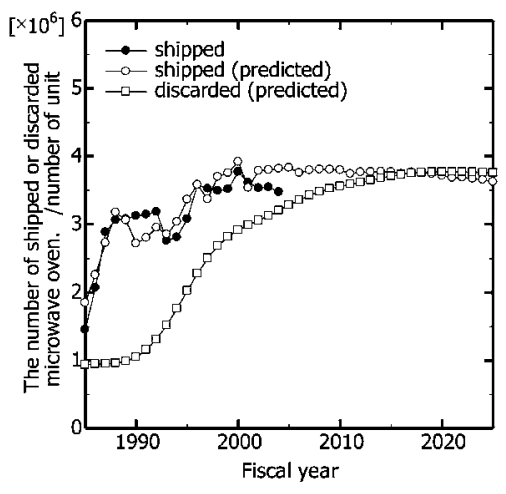

Fig. 1 The estimated number of shipped or discarded microwave oven.

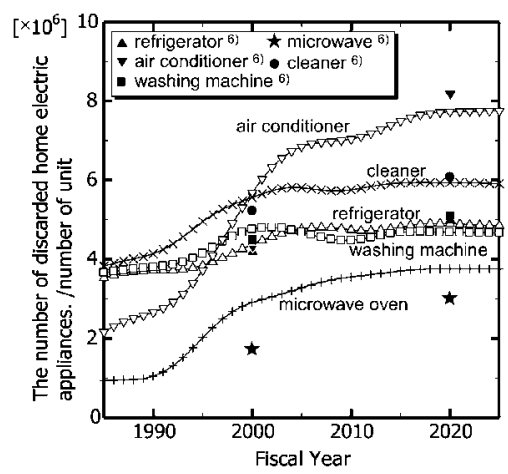

Fig. 2 The estimated number of discarded refrigerator, air conditioner, washing machine, microwave oven, cleaner. The solid marks indicate the reported values.

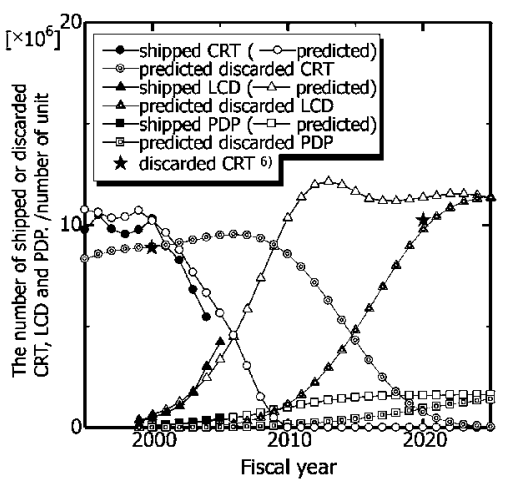

Fig. 3 The predicted number of shipped or discarded CRT, LCD and PDP compared with the previous report.
た，各家電製品の平均重量を用いて廃棄重量を推算すると， 冷蔵庫がもっとも重く約 40 万トン, 次にエアコンで約 32 万トンとなり, 廃棄重量の観点からは冷蔵庫とエアコンをよ り重要な対象にすべきであると考えられる.

ただし，家電製品には，レアメタルといった稀少添加材料 が利用されている，今後は，量的な観点の及ならず質的な観 点を考慮したリサイクルの検討・評価が必要となると考えら れる。この『資源の質』を考慮するための資源指標として は，関与物質総量(TMR: Total Materials Requirement) ${ }^{13)}$ 資源枯渴係数 ${ }^{14)}$ などの指標がある。これら資源の質を考慮 した解析結果に関しては，別報にて報告する.

\subsection{CRT, LCD, PDP の推計結果}

Fig. 3 に CRT, LCD, PDP の出荷台数 (統計値), 出荷台 数 (推算值), 廃棄台数 (推算值) を示す. 図には田崎ら ${ }^{6)}$ によ る CRT の廃棄台数予測結果も示している. 出荷台数の推算 值は，LCD，PDP ともに統計值と良い一致を示している. CRT の出荷台数は, 「LCD と PDP の出荷台数の合計值が CRT の出荷台数の減少台数になる」と仮定して推算してい るが，これが統計值と良い一致を示していることから，消費 者は既設の CRT に加えて LCD や PDP を購入するのではな く，CRTを購入する代わりに LCD や PDP を購入している と推察できる. また，「LCD と PDP の最大保有台数の合計 が，LCD と PDP が存在しないと仮定したときのCRT の最 大保有台数の值に等しい」とした仮定も非現実的なものでは なく，2020２025 年には，映像表示機器の総保有台数がそ れほど変わることなく, 従来の CRT が LCD や PDP に代替 された生活が予測される．ここで，LCD の出荷台数の推算 值に着目すると，2011～13 年にかけて最大值を迎えており， 2011 年 7 月のアナログ放送終了の時期に重なっている。こ れは技術革新による LCD の低価格化なども理由として考え られるが，ロジスティック関数で分析する限り，LCD 市場 がアナログ放送の終了に影響を受けていること示唆している ように思われる.

CRT の廃棄台数に着目すると, 2006 年以降減少に転じ, 2025 年にはほぼ 0 に近い值となっている。ただし，実際に は 2011 年以降のアナログ放送の終了に伴いデジタル放送非 対応型 CRT の製品寿命は急速に短くなると考えられ，より
早い時期に廃棄台数が 0 になるものと考えられる. 現在, CRT のブラウン管は手解体でパネル部とファンネル部に分 離されてリサイクルされているが，国内のブラウン管生産量 が激減しているため, 今後の有効利用法が契緊の課題となっ ている. 現在, ブラウン管ガラスカレットについては, 平成 16 年 5 月より, 国内業界団体が作成したガイドライン15)に 従って蛍光体等被覆物質が除去されたものについては, バー ゼル国内法 (特定有害廃棄物等の輸出入等の規制に関する法 律)上の規制非対象物と整理されて抢り ${ }^{16)}$ ，海外工場におい て水平リサイクルする道が開きつつある。しかし，これはブ ラウン管中に含まれている大量の資源を失うことを意味して おり，他のリサイクル方法を検討する必要があると考えられ る.

LCD や PDP の廃棄台数も急速に増加しており，2020 年 には田崎ら ${ }^{6)}$ が推算した CRT の廃棄台数に近い值の LCD が 廃棄されることが分かる．LCD や PDP には有用資源が多く 含まれているが，特に透明電極用に用いられているインジウ ムの回收は，シャープによる基礎技術の開発が報告されてい る17)が，現在は実証プラントで検証中の段階であり，早急 に回収抢よびリサイクル手法を確立する必要性があると考え られる。

\subsection{VCR, DVD の推計結果}

Fig. 4 に VCR, DVD の出荷台数 (統計値), 出荷台数 (推

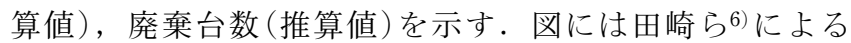
VCR の廃棄台数予測結果も示している，VCR の推算におい ても CRT の場合と同じ仮定を用いているが，統計値と推算 值が比較的良い一致を示した。すなわち，消費者はVCRを 購入する代わりに DVD を購入し，2020～2025 年には, 家 庭内の録画機器の総保有台数がそれほど変わることなく, 従 来のVCR が DVD に代替されると推察される.

VCR の廃棄台数については, CRT の場合と同様の減少が 見られ，DVDについては大きな増加が見られた．今後，こ の状況を基にリサイクルや処分方法を検討する必要があると 考えられるが，すでに述べたようにDVD 機器には DVD プ レーヤ，DVDレコーダ，HDD/DVD レコーダなど多様化が 進んでいるため, より適切な計画を立てるためにはこれら個 別の廃棄台数についての重要性が高くなると考えられる. 


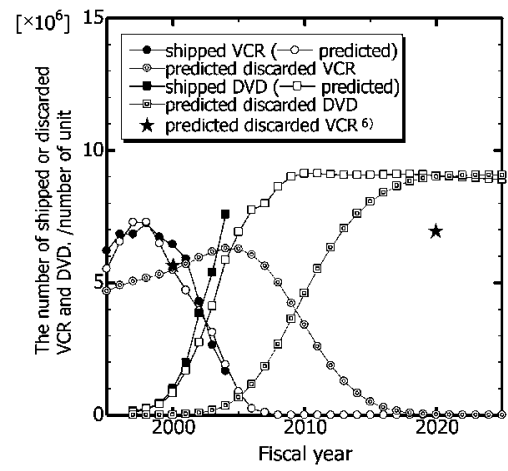

Fig. 4 The predicted number of shipped and discarded VCR and DVD compared with the previous report.

\section{4. 廃棄台数の推算値の応用}

すでに述べたとおり，家電製品の廃棄量推算值は，今後の リサイクルや適正処分をより計画的に遂行する上で重要な データの一つになりうるが，特に近未来の課題となるレアメ タルのリサイクル, 社会蓄積, 拡散を推算する上で重要な基 礎データとなりうる，そこで，以下では廃棄される LCD お よび PDP に含まれるインジウム量の推算を応用例の一つと して行った。推算に必要な液晶パネル中のインジウム量は 15 インチあたり $1 \mathrm{~g}$ という報告值を使った ${ }^{17)}$. また，LCD と PDP の液晶の平均サイズは家電製品協会のへのヒアリン グを基にそれぞれ 22 インチ，39 インチと仮定し，そこに含 まれるインジウム量は面積比で増加するとした.

以上の条件の下, 推算した廃 LCD, 廃 PDP に含まれるイ ンジウム量を Fig. 5 に示す. LCD や PDP がリサイクルさ れずに廃棄されるとインジウムは失われ，その量は年度を追 う毎に急増し, 2025 年以降は年間 35 トン以上のインジウム が市中に拡散することが分かる. 2004 年度に国内で使用さ れた透明電極用インジウム (純分) は PC や携帯電話用液晶パ ネルなどを全て含めて 470 トンとされており17)，その製品 への歩留まりを 3〜 5\%とすると，14２4トンのインジウム が使用されていることになるが，20 年後にはこの 2 倍程度 のインジウムが毎年消失することになる．このことからも液 晶パネル中のインジウムについて, 早急に回収抢よびリサイ クル手法を確立する必要性があることが分かる。

\section{5. よ め}

本研究では CRT, 冷蔵庫, エアコン, 洗濯機, 掃除機, 電子レンジ, VCRの廃棄台数予測に加え, 近年代替新製品 として現れた LCD, PDP, DVDの廃棄台数予測をポピュ レーションバランスモデルを用いて行うことを目的として研 究を進めた。 その結果, 以下のことが明らかになった。

過去に推計例のあった冷蔵庫, エアコン, 洗濯機, 掃除 機, 電子レンジについては 2005 年度のデータを用いて再推 計を行い, 保有台数がほぼ飽和状態にある冷蔵庫, 洗濯機, 掃除機については過去の報告值と同程度であったが，世帯あ たりの保有台数が増加傾向にあるエアコンと, 電子レンジに ついては 30〜 40\%程度の相違が見られた． LCDとPDPの

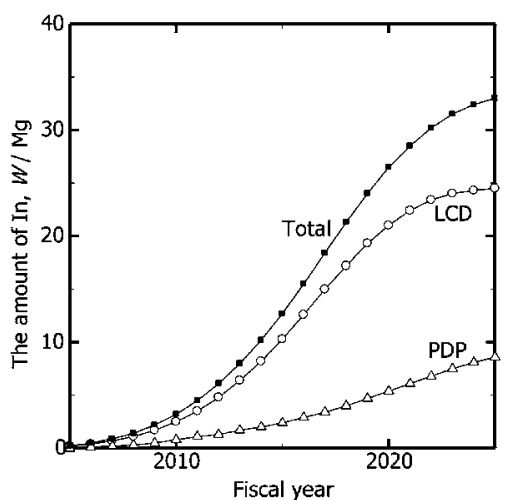

Fig. 5 The estimation of the dissipated amount of indium from LCD and PDP when discarded LCD and PDP are not recycled.

推計に関しては，1.「LCD, PDP の寿命関数は CRT と同じ になる」，2.「LCD と PDP の出荷台数の合計值が CRT の出 荷台数の減少台数になる」および 3 .「LCD と PDP の最大 保有台数の合計が，LCD と PDP が存在しないと仮定したと きの CRT の最大保有台数の值に等しい」という仮定の下推 計を行い, 出荷台数の統計值と推測值の良い一致が見られた. VCR とDVD についても同じ仮定で推算を行ったところ, 出荷台数の統計值と推測值に良い一致が見られた。 また, CRT と VCR の廃棄台数に着目すると, それぞれ 2006 年度 および 2004 年度以降減少に転じ， 2025 年度および 2020 年 度にはほぼ 0 になることが分かった。 また，LCD と PDP が リサイクルされずに廃棄されることにより回収できなくなる インジウム量を推算し， 2025 年以降は年間 35 トン以上のイ ンジウムが市中に拡散することが分かった。

\section{文献}

1) Ministry of the Environment: Junkangata-Syakai-Hakusyo (in Japanese) (2005).

2) Association for electric home appliances: Kadensangyou Handbook 2005 (in Japanese) (2005).

3) Association for electric home appliances: Haikadenseihin-hasseiryou-no-yosokuchousakenkyuu-houkokusyo (in Japanese) (1993).

4) Ministry of Economy, Trade and Industry: Haikibutsutou-syorisaishigenka-suishin-jigyou Houkokusyo (in Japanese) (1998).

5) The Japan Electrical Manufacturers' Association: 2003nen-niitaru-kadenseihinn-no-kokunaijuyouyosoku (in Japanese) (1999).

6) T. Tasaki, M. Oguchi, T. Kameya and K. Urano: Journal of the Japan Society of Waste Management Experts 12(2001) 49-58.

7) Industrial structure Council and Central Environment Council: Dai-2kai-goudou-kaigi, Giji-shidai3-2 (in Japanese) (2002).

8) Agency for Natural Resources and Energy: Denryoku jukyuuno-gaiyou (in Japanese) (Chuwa Printing, 1980-2000).

9) Statistics Bureau of Ministry of Internal Affairs and Communications: Population Census (in Japanese) $(1980-2000)$.

10) National Institute of Population and Social Security Research: Nihon-no-Setaisu-no-Syouraisuikei (in Japanese) (2005).

11) T. Honma: Sugakuteiri Koushiki-syojiten (in Japanese), (Seibunshinsya publishing, 1992) pp. 421-422.

12) Association for electric home appliances: Kaden-seihin-syouhisya-shiyou-jittai-chousa (in Japanese) (2001).

13) K. Halada, K. Ijima, N. Katagiri and T. Okura: J. Japan Inst. Metals 65(2001) 564-570.

14) Keiichi N. Ishihara and Eiji Yamasue: Energy and Resources (in Japanese) 24(2003) 184-187.

15) Electric glass industry association and Association for electric home appliances: Refined CRT caret no Hinshitsu Guideline (2003).

16) Industrial Science and Technology Policy and Environment Bureau of Ministry of Economy, Trade and Industry: Asia Recycle Saizensen, Research Institute of Economy, Trade and Industry (2005).

17) JOGMEC: Koubutsu-Shigen Material flow (in Japanese) (2005). 